\title{
Organic zinc supplementation in the dry season in nelore bulls and its effect on spermiogram
}

\section{Suplementação com zinco orgânico na estação seca em touros nelore e seu efeito no espermiograma}

\author{
Bruna Cardin Hoffig Ramos ${ }^{1}$; Clóvis Franco de Souza²; Priscilla Gomes Carneiro; \\ Aline Tramontini Zanluchi ${ }^{4}$; Fabíola Cristine de Almeida Rêgo ${ }^{5}$; \\ Flávio Guiselli Lopes ${ }^{5}$; Luiz Fernando Coelho Cunha Filho ${ }^{5 *}$
}

\begin{abstract}
The objective of this study was to evaluate the effect of a diet supplementation with 500mg organic zinc (Zn) on sperm morphological characteristics (mass motility, individual motility, and sperm livability) as well as minor and major sperm defects in Nelore bulls during the dry season of 2010, the pluviometric precipitation during the experimental period which occurred from April to October, was $69 \mathrm{~mm}$ from April to August. Thirty-six bulls were selected and divided into two groups of 18 bulls. They were fed the supplemented diet for 180 days. The animals in the first group (G1) were supplemented with an average of 48,89ppm/ $/ \mathrm{kg}$ MS Zn, and the animals in the second group (G2) were supplemented with $115,09 \mathrm{ppm} /$ $\mathrm{kg}$ DM Zn. Data was analyzed with Minitab 13.0. The results of the morphological characteristic of sperm G1 and G2 were higher at 180 days compared to Day zero, especially in vigor and mass motility, with only statistically significant difference in each group, not differentiating between groups. The organic zinc did not affect the morphological characteristic of sperm in Nellore bulls in the dry season. Key words: Bovine, zebu cattle, micro minerals, andrological, winter
\end{abstract}

\section{Resumo}

O objetivo deste estudo foi avaliar a suplementação com $500 \mathrm{mg}$ de zinco orgânico (Zn) sobre a característica morfológica dos espermatozóides e o libido em touros Nelore, características físicas (turbilhonamento, motilidade em massa e vigor) e defeitos espermáticos maiores e menores, no período seco de 2010, a precipitação pluviométrica durante o período experimental, que compreendeu de abril a outubro, foi de $69 \mathrm{mmm}$ de abril a agosto. Trinta e seis touros foram selecionados e divididos em dois grupos de 18 animais, G1 controle e G2 suplementado durante 180 dias. Os dados foram analisados utilizando o Minitab 13.0. Os animais receberam uma média de 48,89 ppm/ kg MS de zinco no G1 e 115,09 ppm/ kg DM em G2. Os resultados da característica morfológica espermática de G1 e G2 foram superiores aos 180 dias em relação ao dia zero, especialmente em vigor e a motilidade em massa, somente com diferença estatisticamente significativa em cada grupo, não diferenciando entre os grupos.

\footnotetext{
${ }^{1}$ Médica Veterinária Autônoma, Londrina, PR. E-mail: bruna_hofig@hotmail.com

${ }^{2}$ Médico Veterinário Especialista em Reprodução e Medicina de Animais de Produção, Universidade Estadual de Londrina, UEL, Londrina, PR. E-mail: clovisfranco38@gmail.com

${ }^{3}$ Discente de Mestrado do Programa de Mestrado em Saúde e Produção de Ruminantes, Universidade Norte do Paraná, UNOPAR, Arapongas, PR. E-mail: pirt1987@hotmail.com

${ }^{4}$ Prof ${ }^{a}$ M.e de Patologia Clínica, UNOPAR, Arapongas, PR. E-mail: alinetramontinizanluchi@gmail.com

${ }^{5}$ Prof $^{\text {as }}$ Dr $^{\text {as }}$ do Programa de Mestrado em Saúde e Produção de Ruminantes, UNOPAR, Arapongas, PR. E-mail: fabiola_rego@ yahoo.com; lopesufv@yahoo.com.br; luiz.cunha@unopar.br

* Author for correspondence
} 
O zinco orgânico não afetou as características morfológicas dos espermatozóides em touros Nelore na estação seca.

Palavras-chave: Bovinos, zebuínos, micro minerais, andrológico, inverno

\section{Introduction}

Brazil has one of the greatest commercial bovine herd in the world, and the reproductive aspects reflect on the zootechnical rates and in the productivity of these herds, as well as on generating profit.

The importance of the bull in reproduction is appreciated by its offspring, and the andrological examination is an important tool to evaluate this aspect. Physical and morphological aspects of semen, testicular biometry, weight gain and sexual behavior must be a part of the andrological examination in order to predict a bull's reproductive potential (LOPES et al., 2009).

Sperm quality is one of the main aspects to consider when evaluating bull's ability to participate in a breeding program. Therefore, sperm morphology is the most trustable parameter in the spermiogram, and together with a clinical and genital evaluation of the bull, they provide detailed information on the fertility potential of the bulls in a breeding program (BARBOSA; SOUZA, 2005).

Pastures in the tropical dry forest regions have low soil fertility and, for this reason, special attention has been directed to zinc has because of its low concentration in the mineral profile of different grasses used for bovine production. About $42 \%$ of farms in the midwest regions have low zinc concentrations in pastures, a concentration below the minimum amount (20ppm) required for animal production (MANDAL et al., 2007).

Diet zinc concentration affects semen quality of bulls in the pubertal period, especially considering sperm morphology, and is related to increasing defects in the mid piece and tail. Consequently, sperm motility decreases and there is a high incidence of defects on sperm head of those animals that did not receive zinc supplementation in the mineral mixture
(OLIVEIRA et al., 2007; FERNANDES et al., 2009).

In spite of the great importance of zinc in the male reproductive system, very few studies have been conducted in bovine in reproductive age in Brazil.

The present study has the objective of evaluating the influence of organic zinc supplementation on sperm morphological and physical features (mass motility, individual motility, and sperm livability) as well as minor and major defects, and the libido in Nelore bulls, during the dry season.

\section{Materials and Methods}

The experiment was conducted in a farm in Anaurilândia, MS. Pluviometric precipitation during the experimental period, which occurred from April to October, 2010, was 69mm from April to August, and $374 \mathrm{~mm}$ in September and October, indicating the dry period. Thirty six purebred Nelore bulls were randomly selected from a herd of 120 bulls, from 5 to 11 years old (he average was 7,833 with the youngest ageing 5,5 years old and the oldest, 11, weighting around $650 \mathrm{~kg}( \pm 91,45$ $\mathrm{kg})$, with body condition score of $4(3,879 \pm 0,096)$ and kept on a paddock for grazing. Animals were divided into two groups, comprised of 18 animals in each group, G1 (control) and G2 (supplemented). In $\mathrm{G} 2$ the animals were given $5 \mathrm{~g} \mathrm{Zn}$-methionine (500mg organic zinc) daily, added in the mineral supplement, during 180 days. Both groups were kept in two continuous paddocks with Brachiaria brizantha grass. They were altered weekly in order to avoid the effect of soil and pasture. The bulls received mineral supplementation in the initial period, complemented with urea during the dry period. Samples of grass, soil and water 
were collected and sent to the soil laboratory of Universidade Estadual de Maringá (UEM) to determine the concentration of zinc. Semen samples were collected on days 0 and 180 by electroejaculation. Day 1 (D-1) represents de day when the first andrological exam was performed, during the previous breeding season in 2009. After semen collection on D0 and D180, the bulls were submitted to a libido evaluation according to a reference proposed by Santos (1999). The samples were immediately analysed, and parameters such as motility and sperm livability were compared between G1 and G2. An aliquot of each sample was sent to Universidade Federal de Minas Gerais for evaluating and classifying pathologies (FONSECA et al., 1992). All procedures were executed respecting the requirements of Ethics Committee for Animal Experimentation (approved by ECAE/ UNOPAR n⿳006/11). For statistical analysis of data, the statistical package Minitab 13.0 was used; quantitative data underwent a variance analysis with a 5\% minimum significance level; and, in turn, data regarding the correlations was addressed through Pearson's coefficient. This coefficient (r) between testosterone concentration and libido was used to measure the correlation between these two quantitative variables.

\section{Results and Discussion}

The results obtained regarding the concentration of zinc in the diet were $0,04 \mathrm{ppm}$ on water, $3,58 \mathrm{ppm}$ on soil, and 17,34ppm DM in the pasture. These numbers correspond to a mean daily food intake of $12,8 \mathrm{ppm} \mathrm{MS}$, which is bellow recommendation (NRC, 2000) for beef cattle (30ppm DM/day), indicating the need for zinc supplementation. In another research involving Brachiaria brizantha in Mato Grosso do Sul, has found similar results on the concentration of zinc in the pasture (13ppm DM) on dry season (OLIVEIRA, 2006). Mandal et al. (2007) emphasize the need for zinc supplementation in farms on the midwest region in Brazil.
The mineral mixture individual daily intake in the initial period of the experiment in G1 was $151,36 \mathrm{~g} /$ animal/day, and in G2 the consumption was $152,54 \mathrm{~g} /$ animal/day. During the period when mineral mixture was added to concentrate protein, feed intake was 237,31/animal/day for G1 and 241,43g/animal/day for G2, adding up a mean amount of 48,89ppm DM of zinc for G1 and 115,09pmm DM of zinc for G2. Dry matter intake was $2 \%$ body weight (NRC, 2000). Therefore, the mineral mixture intake was higher than that indicated by the manufacturer $(80 \mathrm{~g} /$ animal/day). There was no difference in the mineral mixture consumption between the two groups when regarding palatability. This observation differs from a research which reports a significantly higher consumption in the group that was not receiving zinc supplementation since zinc has low palatability (OLIVEIRA, 2006).

Mean serum zinc levels in both groups are described in table 1, and are lower than those found in literature (REBHUN, 2000), that range from 0,8 $\mu \mathrm{g} / \mathrm{mL}$ to $1,2 \mu \mathrm{g} / \mathrm{mL}$ for bovine.

Table 1. Means and standard deviation of serum zinc concentration $(\mathrm{mg} / \mathrm{dL})$ in 36 Nelore bulls in two different groups and times.

\begin{tabular}{ccc}
\hline GROUP & D0 & D180 \\
\hline $\mathbf{1}$ & $0,6245 \pm 0,0649^{\mathrm{aA}}$ & $0,6544 \pm 0,1220^{\mathrm{aA}}$ \\
$\mathbf{2}$ & $0,6327 \pm 0,0996^{\mathrm{aA}}$ & $0,6864 \pm 0,1052^{\mathrm{aA}}$ \\
\hline
\end{tabular}

Small letters on the same column indicate no significant difference $(p<0,05)$

Capital letters on the same line indicate no significant difference $(\mathrm{p}<0,05)$.

Source: Elaboration of the authors.

Statistical analysis demonstrate no significant differences between the groups, therefore there is no increase in zinc serum levels after 180 days. However, the literature reports results obtained in dairy cows and in Bos taurus. For this reason, we raise a question whether Nelore bulls might present a lower zinc serum concentration. 
The results obtained in this research, indicating that zinc serum concentration has not been influenced by zinc supplementation, have been demonstrated in another study (CUNHA FILHO et al., 2009). Nevertheless, some studies report a higher zinc serum concentration in animals feed a diet supplemented with excess zinc, when compared to a control diet (WRIGHT; SPEARS, 2004).
The mean values in the spermiogram from the 36 bulls on D-1, on D0 and on D180 are described in table 2. Both G1 and G2 showed superior spermiogram parameters on D180 when compared to D0, particularly in sperm livability and mass motility, with statistical difference in each group. However, when comparing spermiogram between control and treatment groups, there was no statistically significant difference in the results.

Table 2. Means and standard deviation on spermiogram parameters of 36 Nelore bulls in two different groups and times.

\begin{tabular}{ccccc}
\hline PARAMETER & GRUPO & D-1 & D0 & D180 \\
\hline MOTILITY & 1 & $74.4 \pm 9,8^{\mathrm{aA}}$ & $76.4 \pm 11,0^{\mathrm{Aa}}$ & $83.3 \pm 2,97^{\mathrm{aA}}$ \\
& 2 & $76.1 \pm 11,0^{\mathrm{aA}}$ & $72.8 \pm 15,0^{\mathrm{aA}}$ & $84.1 \pm 1,96^{\mathrm{aA}}$ \\
VIGOR & 1 & $3.9 \pm 0.90^{\mathrm{aA}}$ & $4.3 \pm 0.89^{\mathrm{aAB}}$ & $4.8 \pm 0.38^{\mathrm{aBC}}$ \\
MASS MOTILITY & 2 & $4.3 \pm 0.69^{\mathrm{aAB}}$ & $4.2 \pm 0.88^{\mathrm{aA}}$ & $4.8 \pm 0.33^{\mathrm{aBC}}$ \\
& 1 & $2.3 \pm 2.08^{\mathrm{aA}}$ & $2.3 \pm 1.97^{\mathrm{aA}}$ & $3.7 \pm 1.19^{\mathrm{aAB}}$ \\
MAJOR DEFECTS & 2 & $2.8 \pm 2.01^{\mathrm{aA}}$ & $2.3 \pm 2.03^{\mathrm{aA}}$ & $3.9 \pm 1.52^{\mathrm{aB}}$ \\
& 1 & $6.3 \pm 10.13^{\mathrm{aA}}$ & $5.2 \pm 6.10^{\mathrm{aA}}$ & $2.7 \pm 3.09^{\mathrm{aA}}$ \\
TAIL DEFECTS & 2 & $4.6 \pm 5.04^{\mathrm{aA}}$ & $5.9 \pm 4.91^{\mathrm{aA}}$ & $3.9 \pm 4.46^{\mathrm{aA}}$ \\
& 1 & $2.00 \pm 7.03^{\mathrm{aA}}$ & $1.33 \pm 3.03^{\mathrm{aA}}$ & $0.67 \pm 1.24^{\mathrm{aA}}$ \\
IP DEFECTS** & 2 & $1.28 \pm 2.22^{\mathrm{aA}}$ & $1.17 \pm 1.89^{\mathrm{aA}}$ & $0.72 \pm 1.07^{\mathrm{aA}}$ \\
& 1 & $0.67 \pm 1.37^{\mathrm{aA}}$ & $0.67 \pm 1.03^{\mathrm{aA}}$ & $0.06 \pm 0.24^{\mathrm{aA}}$ \\
MINOR DEFECTS & 2 & $0.94 \pm 1.59^{\mathrm{aA}}$ & $1.00 \pm 1.53^{\mathrm{aA}}$ & $0.17 \pm 0.38^{\mathrm{aA}}$ \\
& 1 & $12.0 \pm 10.73^{\mathrm{aA}}$ & $11.3 \pm 10.59^{\mathrm{aA}}$ & $7.2 \pm 6.85^{\mathrm{aA}}$ \\
\hline
\end{tabular}

*Andrological exam done in September, 2009.

**IP: intermediate piece.

Small letters on the same column indicate no significant difference $(p<0,05)$.

Capital letters on the same line indicate no significant difference $(p<0,05)$.

Source: Elaboration of the authors.

A higher zinc daily intake in the control group (G1) of 48,89ppm DM/day, an amount of $60 \%$ higher than the recommended by NRC (2000), may explain the similarity of the results obtained for both groups. The results found in the spermiogram are similar to those obtained by Oliveira (2006) who reported that animals that receive a zinc supplementation in mineral mixture did not demonstrate significant variations on spermiogram.

Another factor that may have influenced the results is that the reports on sperm alterations in bulls occur, specifically in young bulls, during pubertal phase (KUMAR et al., 2006; FERNANDES et al., 2009), what might explain the absence of significant statistical differences in the results in G1 and G2, composed of mature bulls with mean ages of 8 years old. Another important factor that may have influenced the results is the fact that the farm had been having success on the selection of bulls with precocious sexual maturity and great semen quality. Statistical analysis of the results did not show any correlation between the bulls age and sperm 
features analyzed, both in G1 and G2. Therefore, the youngest bulls from this study were sexulay mature $(\mathrm{P}=0,463)$.

Contradicting the results obtained in this work, Kumar et al. (2006) obtained better semen quality after feeding zinc supplemented diet to 16 cross bred bulls. Comparing this group with non-supplemented group, they also demonstrated that those animals supplemented with zinc reached significant resultas in terms of quantitative and qualitative parameters, such as ejaculated volume, motility and sperm concentration.

Serum testosterone concentration in G1 was 285,28 $\pm 142,93$ (ng/dL) and 294,39 $\pm 188,86$ (ng/dL) in G2, with no significant difference between the groups. Thus, zinc supplementation did not influence serum levels of testosterone. These results were similar to the ones described for Nelore bulls $(293,72 \pm 18,25$ $\mathrm{ng} / \mathrm{dl}$ ) (LEZIER, 2004), although these results were higher than $159 \mathrm{ng} / \mathrm{dL}$ for Nelore bulls (SANTOS, 1999) and lower than the organic zinc supplemented group (352 ng/dL) obtained by Kumar et al. (2006).

Regarding the libido results on day 180, bulls from G1 had a mean of $82.8 \pm 23.21$, and G2 (treatment group) had a mean of $90.0 \pm 10.33$, concluding that organic zinc supplementation did not influence the bulls sexual behavior. In the present study, there was no significant correlation between libido and testosterone levels, for G1 $(p=0,443)$ and for $\mathrm{G} 2$ $(p=0,373)$, which is in agreement with another report for Nelore bulls (SANTOS, 1999).

\section{Conclusion}

The element zinc did not influence the spermiogram of Nelore bulls supplemented with the mineral during the dry season.

\section{Referências}

BARBOSA, F. A.; SOUZA, G. M. de. Influência dos principais microminerais na reprodução de bovinos.
Belo Horizonte: ReHAgro, 2005. 4 p. (Artigos técnicos).

FONSECA, V. O.; VALE FILHO, N. R.; MIES FILHO, A.; ABREU, J. J. de. Procedimentos para exame andrológico e avaliação de sêmen animal. Belo Horizonte: Colégio Brasileiro de Reprodução Animal, $1992,79 \mathrm{p}$.

CUNHA FILHO, L. F. C.; CHIACCHIO, S. B.; GASTE, L.; GONÇALVES, R. C.; VIANNA, L. C. Concentração do zinco sérico em vacas leiteiras suplementadas com Saccharomyces cerevisiae, portadoras ou não de lesões podais. Semina: Ciências Agrárias, Londrina, v. 30, n. 2, p. 425-430, abr./jun. 2009.

FERNANDES, C. E.; MIRANDA, P. A. B.; LOPES, S. C. P.; MORAES, S. S.; MORAIS, M. G.; ABREU, U. G. P.; LANDIM-ALVARENGA, F. C. Alterações na morfologia espermática em touros de corte com e sem suplementação de zinco na mistura mineral. Ciência Animal Brasileira, Goiânia, v. 10, n. 4, p. 1074-1083, out./dez. 2009.

KUMAR, N.; VERMA, R. P.; SINGH, L. P.; VARSHNEY, V. P.; DASS, R. S. Effect of different levels and sources of zinc supplementation on quantitative and qualitative semen attributes and serum testosterone level in crossbred cattle (Bos indicus x Bos taurus) bulls. Reproduction Nutrition Development, v. 46, n. 6, p. 663-675, 2006.

LEZIER, D. H. Avaliação da biometria testicular, concentração plasmática de hormônios e minerais em bovinos Nelore variedade mocha dos 12 aos 24 meses de idade. 2004. Tese (Doutorado em Medicina Veterinária) - Departamento de Reprodução Animal e Radiologia Veterinária. Universidade Estadual Paulista, Botucatu.

LOPES, F. G.; GUIMARÃES, J. D; COSTA, E. P.; CARVALHO, G. R.; MIRANDA NETO, T. Avaliação andrológica por pontos e comportamento sexual em touros da raça Nelore. Revista Brasileira de Zootecnia, v. 38, n. 6, p. 1018-1025, 2009.

MANDAL, G. P.; DASS R. S.; ISORE, D. P.; GARG, A. K.; RAM, G. C. Effect of zinc supplementation from two sources on growth, nutrient utilization and immune response in male crossbred cattle (Bos indicus $\times$ Bos taurus) bulls. Animal Feed Science and Technology, Amsterdam, v. 138, in. 1, p. 1-12, 2007.

NUTRIENT REQUIREMENTS OF BEEF CATTLE NRC. Zinc. $7^{\text {th }}$ ed. Washington: D. C., National Academy Press, 2000.

OLIVEIRA, A. R. Efeito de diferentes fontes e concentrações de zinco na mistura mineral sobre desempenho e características seminais de touros jovens criados em campo. 2006. Dissertação (Mestrado em Produção Animal) - Programa Mestrado em Ciência 
Animal. Universidade Federal de Mato Grosso do Sul, Campo Grande, MS.

OLIVEIRA, A. R. de.; MORAIS, M. G.; MORAES, S. S.; FERNANDES, C. E.; ÍTAVO, L. C. V.; ABREU, U.G.

P. Efeito de diferentes fontes e concentrações de zinco na mistura mineral sobre desempenho e características seminais de touros jovens criados em campo. Ciência Animal Brasileira, Goiânia, v. 8, n. 3, p. 465-477, 2007.

REBHUN, W. C. Doenças do gado leiteiro. São Paulo: Roca, 2000. 305 p.
SANTOS, M. D. Comportamento sexual, qualidade seminal e eficiência reprodutiva de touros da raça Nelore em regime de monta natural. 1999. Tese (Doutorado em Zootecnia) - Departamento de Produção Animal. Universidade Federal de Viçosa, Viçosa, MG.

WRIGHT, C. L.; SPEARS, J. W. Effect of zinc source and dietary level an zinc metabolism in holstein calves. Journal of Dairy Science, Madison, v. 87, n. 4, p. $1085-$ 1091, 2004. 